\title{
BUDIDAYA PADI PADA LAHAN SAWAH BUKAAN BARU WILAYAH PERBATASAN KABUPATEN MERAUKE
}

\author{
(Rice Cultivation On The Palm Land Open New Border Region Of Merauke Regency) \\ Petrus A Beding, Fransiskus Palobo, Batseba M.W. Tiro \\ Balai Pengkajian Teknologi Pertanian Papua \\ Jl. Yahim No. 49, Sentani, Jayapura - Papua 99352 \\ Telp (0967) 592179, Fax (0967) 591235 \\ Corresponding author : frans.merauke@gmail.com
}

Article Submitted : 19-09-2019

Article Accepted : 03-10-2019

\begin{abstract}
Merauke Regency is one of the districts in Papua Province which borders directly with neighboring Papua New Guinea (PNG), which in addition is a rice development area. In general, new openings, poor physical and chemical properties with porous soils, thin layer, low organic matter content, high salinity and drought problems. This study aims to determine the productivity of rice in new openings in the border region. The study was conducted in Merauke Regency, Papua Province from April to August 2018. The design used was a factorial Randomized Block Design with 5 factor children, each variety used was Inpari-32, Inpari-33, Inpari-43, Inpara-8, Dodok Erok. The results of the study were acid soil $\mathrm{pH}$ status, high and very high organic matter, very low cation exchange rate. The components of growth in plant height, productive tillers and panicle length were not significantly different. The yield component was significantly different in the highest number of unripe per-panicle Inpara-8 $(140.3 \mathrm{~g})$, the highest empty grain per panicle Inpara-8 (55.5 grains) and the 1000 heaviest Dodok Erok 29.4 g. Whereas Grain content, Dry Grain Harvest is not real.
\end{abstract}

Keywords: Rice Cultivation, New Openings, Borders

\section{PENDAHULUAN}

Percepatan pembangunan pertanian di wilayah perbatasan, khususnya wilayah perbatasan di bagian timur Indonesia, harus dilakukan secara komprehensif, mencakup aspek teknis dan teknologi, social-budaya, dan ekonomi (Suradisastra 2011). Menurut FKPR (2014) Kabupaten Merauke termasuk prioritas dalam koridor 6 MP3EI (Master Plan Percepatan Pembangunan Ekonomi Indonesia). Kabupaten Merauke merupakan salah satu kabupaten di Provinsi Papua yang berbatasan langsung dengan Negara tetangga Papua New Guinea (PNG), yang selain merupakan kawasan pengembangan padi. Sampai pada tahun 2017, program pencetakan sawah baru di Kabupaten Merauke mencapai 7.115 ha (Dinas Tanaman Pangan dan Hortikultura Kabupaten Merauke, 2017). Menurut Ritung dan Suharta Potensi pengembangan sawah baru non-rawa sebesar 5.297.593 ha. Berdasarkan data dari Direktorat Perluasan Areal (2007), luas lahan sawah bukan baru pada tahun 2006 adalah seluas 6.764 ha, tersebar di 75 kabupaten pada 22 Provinsi. Untuk tahun 2007 Direktorat Perluasan Areal merencanakan pencetakan sawah pada 99 wilayah kabupaten seluas 18.446 ha.

Peningkatan produksi padi selain untuk memenuhi kebutuhan pangan penduduk, 
juga sebagai sumber pendapatan rumah tangga petani produsen (Suphendi et al. 2014). Badan Litbang Pertanian telah menghasilkan berbagai inovasi teknologi yang mampu meningkatkan produksi padi, di antaranya varietas unggul baru. Sebagian dari varietas unggul baru yang dihasilkan melalui penelitian telah dikembangkan petani.

Penduduk Indonesia dari tahun ke tahun semakin bertambah dengan pertumbuhan sekitar 1,5\% tahun-1, sehingga mendorong permintaan pangan terus meningkat. Sementara lahan pertanian khususnya lahan sawah, yang luasnya mencapai 8,08 juta ha (BPS, 2018) ternyata belum mampu memenuhi kebutuhan pangan Indonesia terutama beras, jagung, dan kedelai, sehingga perlu ditambah dengan impor yang pada dekade terakhir jumlahnya meningkat. Irawan (2005) memperkirakan potensi pengadaan beras impor pada tahun 2010 adalah 4,12 juta ton. Agus dan Irawan (2006) memperkirakan bahwa tahun 2025 Indonesia akan harus mengimpor 11,4 juta ton beras jika konversi lahan sawah berjalan secepat 190.000 ha tahun-1 dan pencetakan sawah mencapai 100.000 ha tahun-1.

Permasalahan yang dihadapi pada lahan sawah bukaan baru adalah masalah kesuburan tanah, sehingga produktivitas lahan sawah bukaan baru biasanya jauh lebih rendah dari sawah yang telah mapan. Menurut Sudjadi (1984), lahan sawah yang baru dicetak sering dihadapkan pada berbagai permasalahan kesuburan tanah, sehingga produktivitas lahan sawah bukan baru biasanya jauh lebih rendah dari sawah yang telah mapan. Kendala utama pada pada tanah tersebut adalah rendahnya $\mathrm{pH}$, kandungan bahan organik dan unsur hara tanah seperti $\mathrm{P}$ dan $\mathrm{K}$ yang rendah, serta adanya unsur besi yang dapat meracuni tanaman padi. Selama proses pembentukan sawah baru, sifak fisik tanah mengalami perubahan. Proses reduksi dan oksidasi merupakan proses-proses yang utama yang dapat mengakibatkan baik sifat mineral, kimia, fisika dan biologi tanah (Prasetyo et al. 2004). Perubahan sifat fisik tanah juga banyak dipengaruhi oleh terjadinya iluviasi dan/atau eluviasi bahan kimia atau partilel tanah akibat proses pelumpuran dan perubahan drainase (Hardjowigeno et al. 2014).

Pengelolaan lahan sawah bukaan baru merupakan salah satu faktor penting yang harus diperhatikan sambil melakukan uji varietas padi yang dapat tumbuh adaptif. Pada umumnya lahan sawah bukaan baru sifatnya marjinal sehingga dapat menimbulkan beberapa masalah yaitu kebutuhan air yang banyak untuk pelumpuran, produktifitas tanah yang masih rendah dan proses perubahan pisikokimia akibat penggenangan yang dapat mengganggu pertumbuhan tanaman seperti keracunan besi atau mangan ${ }^{2}$. Jika lahan tidak dikelola secara tepat, akan terjadi gagal panen disebabkan tingginya konsentrasi $\mathrm{Fe}^{2+}$ yang bersifat meracun dan rendahnya kandungan hara makro terutama $\mathrm{P}, \mathrm{K}, \mathrm{Ca}$, dan Mg. Berdasarkan hal tersebut di atas dibutuhkan suatu inovasi teknologi sebagai upaya peningkatan produktivitas padi pada lahan-lahan bukaan baru melalui introduksi pengelolaan tanaman terpadu (PTT) padi.

Seperti pada umumnya sawah bukaan baru, sifat fisik dan kimia tanah kurang baik dengan ciri tanah yang porous, lapisan olahnya tipis, kandungan bahan organik yang rendah, salinitas tinggi serta permasalahan kekeringan. Namun demikian, selain faktor fisik dan kimia, faktor kelembagaan dalam rangka optimalisasi sawah bukaan baru juga menjadi perhatian. Upaya peningkatan produksi pertanian tidak hanya ditentukan oleh faktor teknologi, melainkan juga ditentukan oleh faktor sosial budaya masyarakat setempat. Penelitian ini bertujuan untuk mengetahui produktivitas padi pada lahan sawah bukaan baru di wilayah perbatasan. 


\section{METODE PENELITIAN}

Penelitian dilaksanakan di kampung Salor Distrik Kurik kabupaten Merauke pada bulan April sampai Agustus 2018. Pemilihan lokasi dilakukan secara sengaja

\section{Bahan dan Alat}

Bahan yang digunakan dalam penelitian ini adalah 5 varietas. Ada 4 (empat) varietas produksi Badan Litbang yaitu: Inpara 8, Inpari 32, Inpari 33 , Inpari 43 dan Varietas lokal (Dodo Erok) adatif yang ditanam petani setempat digunakan sebagai pembanding.

\section{Metode Penelitian}

Penelitian menggunakan rancangan acak kelompok satu faktorial yaitu varietas dengan 5 anak faktor: a. Inpara 8, b. Inpari 32, c. Inpari 33, d. Inpari 43, e. Dodo Erok. Sedangkan ulangan sebanyak 3 (tiga). Luas petak percobaan 2 ha untuk masing masing perlakuan adalah $20 \times 20 \mathrm{~m}^{2}$. Sistem tanam Tabela menggunakan jajar legowo 2:1 Analisis Data

Data diolah menggunakan aplikasi DSAASTAT ver. 1.101. Analisis sidik ragam (Anova) dilakukan untuk mendapatkan nilai uji $\mathrm{F}$ pada taraf 5\% dan Apabila Uji $F$ pada sidik ragam menunjukkan pengaruh nyata akan dilanjutkan dengan uji beda nyata terkecil (BNT) pada taraf 5\%.

Peubah yang diamati adalah (1) Hasil gabah ditentukan berdasarkan panen ubinan

\section{HASIL DAN PEMBAHASAN}

Hasil analisis lengkap tanah sebelum dan sesudah di lokasi penelitian dapat lihat pada Tabel 1. Berdasarkan hasil analisis tanah lengkap sebelum diaplikasi pupuk organik tanah di lokasi ini memiliki tekstur liat berdebu dengan tingkat kesuburan rendah, yang dicirikan dengan tingkat

\section{Lokasi dan Waktu Penelitian}

untuk mendukung program Kementan dalam membangun pertanian di kawasan perbatasan.

Tanaman dipupuk dengan Pupuk anorganik 2 ton/ha, NPK $200 \mathrm{~kg} / \mathrm{ha}$, Urea $100 \mathrm{~kg} / \mathrm{ha}$, SP36 $200 \mathrm{~kg} / \mathrm{ha}$. Sedangkan alat yang digunakan yaitu tali tanam, hand spayer, Hand traktor, cangkul, Sabit, timbangan dan karung.

(40:20:10 cm) yang merupakan teknologi unggulan Badan Litbang Kementan (Ikhwani et al., 2013). Sedangkan pengendalian gulma dilakukan dengan mengunakan herbisida pratumbuh yang dikombinasikan dengan penyiangan secara manual sesuai dilapangan.

dengan kebutuhan

pada petakan berukuran 2,5 $\mathrm{m}$ x 2,5 m untuk setiap varietas varietas. Hasil ubinan selanjutnya dikonversi menjadi t/ha (2) Data pertumbuhan dan komponen hasil diambil berdasarkan rata-rata 10 tanaman contoh tiap petak ubinan, meliputi; (a) Tinggi tanaman, (b) Jumlah anakan per rumpun, (c) Jumlah gabah isi per malai, (d) Jumlah gabah hampa per malai, dan (e) Jumlah gabah total per malai.

\section{Analisis Tanah Sebelum dan Sesudah Pemupukan}

kemasaman yang tergolong masam; $\mathrm{pH}$ (H2O) 5,32 dan $\mathrm{pH}$ (KCL) 4,24. Nilai $\mathrm{pH}$ tanah dapat digunakan sebagai indikator kesuburan tanah, karena dapat mencerminkan ketersediaan hara dalam tanah (Hanafiah, 2005). 
Tabel 1. Analisis tanah lengkap

\begin{tabular}{|c|c|c|c|c|}
\hline Uraian & $\begin{array}{c}\text { Sebelum } \\
\text { aplikasi }\end{array}$ & Kriteria $\left.^{*}\right)$ & Sesudah aplikasi & Kriteria $\left.^{*}\right)$ \\
\hline \multicolumn{5}{|l|}{ Tekstur } \\
\hline Pasir (\%) & 10 & Lempung liat & 5 & Lempung liat \\
\hline Debu (\%) & 53 & berpasir & 69 & berpasir \\
\hline Liat $(\%)$ & 37 & & 26 & \\
\hline pH H2O $(1: 2,5)$ & 5,32 & Masam & 5,46 & Masam \\
\hline pH KCL $(1: 2,5)$ & 4,24 & - & 4,40 & - \\
\hline \multicolumn{5}{|l|}{ Bahan organik } \\
\hline Carbon $(\%)$ & 3,94 & Tinggi & 3,94 & Tinggi \\
\hline Nitrogen $(\%)$ & 5,17 & Sangat Tinggi & 0,12 & Sangat Tinggi \\
\hline $\mathrm{C} / \mathrm{N}$ & 37 & Sangat Tinggi & 33 & Sangat Tinggi \\
\hline P2O2 (25\% HCL) & 20 & Tinggi & 17 & Tinggi \\
\hline $\mathrm{K} 2 \mathrm{O}(25 \% \mathrm{HCL})$ & 121 & & 118 & \\
\hline P-Bray (ppm) & 43 & Sangat Tinggi & 78 & Sangat Tinggi \\
\hline Kemasaman (KCL $1 \mathrm{~N})$ & 6,17 & - & 6,05 & - \\
\hline Al-Tukar (KCL 1 N) & 3,38 & - & 3,17 & - \\
\hline H-Tukar (KCL 1 N) & 2,79 & - & 2,88 & - \\
\hline \multicolumn{5}{|l|}{ Nilai Tukar Kation : } \\
\hline $\mathrm{Ca}(\mathrm{me} / 100$ gram) & 1,25 & Sangat rendah & 0,93 & Tinggi \\
\hline $\mathrm{Mg}(\mathrm{me} / 100$ gram $)$ & 0,07 & Sangat rendah & 0,20 & Sangat rendah \\
\hline $\mathrm{K}$ (me/100 gram) & 0,06 & Sangat rendah & 0,08 & Sangat rendah \\
\hline $\mathrm{Na}$ (me/100 gram) & 0,01 & Sangat rendah & 0,04 & Sangat rendah \\
\hline Jumlah & 1,39 & & 1,25 & \\
\hline KTK & 12,41 & Rendah & 16,44 & Sedang \\
\hline KB (\%) & 11 & Sangat rendah & 8 & Sangat rendah \\
\hline
\end{tabular}

Kemasaman tanah akan berakibat langsung terhadap tanaman karena meningkatkan kadar ion-ion hidrogen bebas. Dari segi $\mathrm{pH}$ tanah menunjukkan bahwa tanah sawah di lahan bukaan baru termasuk dalam kriteria kurang sehat. Lowery et al (1996) dalam Irundu (2008), menyatakan bahwa tanah dengan $\mathrm{pH}$ berkisar 4,5-6,5 merupakan tanah dengan kriteria kurang sehat. Sedangkan tanah yang memiliki $\mathrm{pH}$ seimbang atau netral $(\mathrm{pH}$ 6,6-7,5) merupakan tanah dengan kriteria sehat. Reaksi tanah ( $\mathrm{pH}$ tanah) tidka hanya menunjukkan sifat kemasaman atau kebasaan tanah, tetapi juga berkaitan dengan sifat kimia tanah lainnya, misalnya ketersediaan unsur hara fosfor, kation-kation basa dan lain-lain (Hanudin, 2000).

Kandungan C-Organik tinggi (3,94\%), kandungan C-Organik pada tanah merupakan petunjuk besarnya akumulasi bahan organik pada tanah tersebut. Kandungan N-total $(0,12 \%)$ yang tergolong rendah, P-Bray (43 ppm) yang tergolong sangat tinggi. Nilai extract KCL ditemukan cukup tinggi, dengan tingkat kemasaman 6,17, kandungan Al-Tukar cukup tinggi $(3,38)$, kandungan $\mathrm{Al}$ yang tinggi dapat menyebabkan keracunan sehingga pertumbuhan tanaman terganggu.

Nilai tukar kation sangat rendah $(1,39$ me/100 gram), $\mathrm{Ca}$ sangat rendah $(1,25$ me/100 gram), $\mathrm{Mg}$ sangat rendah $(0,07$ me/100 gram), $\mathrm{K}$ sangat rendah $(0,06$ me/100 gram) dan $\mathrm{Na}$ sangat rendah $(0,01$ me/100 gram). Kapasitas tukar kation (KTK) juga tergolong rendah $(12,41 \mathrm{me} / 100$ gram). KTK merupakan sifat kimia tanah erat hubungannya dengan kesuburan tanah. Tanah dengan KTK rendah tidak mampu 
menyerap dan menyediakan unsur hara dengan baik dibandingkan dengan KTK tinggi. KTK tanah menggambarkan kationkation tanah seperti $\mathrm{Ca}, \mathrm{Mg}, \mathrm{Na}$ dan $\mathrm{K}$ dapat ditukar dan diserap oleh perakaran tanaman (Sudaryono, 2009). KTK tanah yang rendah disebabkan karena kandungan liat dan bahan organik yang rendah. Bahan organik

\section{Keragaan Pertumbuhan dan Hasil}

Tinggi tanaman tidak berbeda nyata antar varietas pada berbagai umur pengamatan kecuali pada 30 Hst. Varietas Dodo Erok sebagai pembanding memiliki mempunyai pengaruh yang amat besar atas KTK. Hal ini disebabkan humifikasi menghasilkan koloid yang mempunyai luas permukaan tinggi. Ansori (2005) menyatakan bahwa sekitar 7-20\% KTK sebagian besar bersumber dari bahan organik.

tinggi tanaman $72,87 \mathrm{~cm}$, lebih tinggi dari keempat varietas unggul baru yang dikaji (Tabel 2).

Tabel 2. Tinggi tanaman, jumlah anakan dan panjang malai dari lima varietas.

\begin{tabular}{lcccc}
\hline Varietas & $\begin{array}{c}\text { Tinggi } \\
\text { tanaman } \\
(\mathrm{cm})\end{array}$ & $\begin{array}{c}\text { Deskripsi } \\
\text { Tanaman Padi } \\
(\mathrm{cm})\end{array}$ & $\begin{array}{c}\text { Anakan Produktif } \\
\text { (Rumpun) }\end{array}$ & $\begin{array}{c}\text { Panjang malai } \\
(\mathrm{cm})\end{array}$ \\
\hline Inpari 32 & $59,27 \mathrm{a}$ & 97 & $11,6 \mathrm{a}$ & $18,7 \mathrm{a}$ \\
Inpari 33 & $59,67 \mathrm{a}$ & 93 & $12,3 \mathrm{a}$ & $19,9 \mathrm{a}$ \\
Inpari 43 & $63,80 \mathrm{a}$ & 88 & $14,1 \mathrm{a}$ & $18,8 \mathrm{a}$ \\
Inpara 8 & $66,67 \mathrm{a}$ & 107 & $12,4 \mathrm{a}$ & $21,3 \mathrm{a}$ \\
Dodok Erok & $72,87 \mathrm{a}$ & - & $15,3 \mathrm{a}$ & $20,3 \mathrm{a}$ \\
\hline
\end{tabular}

Keterangan: Angka-angka yang diikuti huruf yang sama pada kolom yang sama menunjukkan tidak berbeda nyata berdasarkan uji lanjut Duncan pada taraf 5\%

Tinggi tanaman merupakan salah satu kriteria seleksi tanaman padi. Tinggi rendahnya tanaman berkaitan dengan ketahanan rebah. Tanaman yang terlalu tinggi umumnya mudah rebah. Oleh sebab itu, tinggi tanaman menentukan penerimaan petani terhadap suatu varietas unggul baru. Petani umumnya kurang menyukai varietas dengan postur tinggi karena produktivitasnya belum tentu tinggi (Endrizal dan Bobihoe 2010). Hasil kajian tinggi tanaman pada inpari 32 menunjukan selisih $37,73 \mathrm{~cm}$ dengan deskripsi tanaman. Inpari 33 ada selisih $33,33 \mathrm{~cm}$, kemudian Inpari-43 menunjukan selisih $24,2 \mathrm{~cm}$ dan Inpara-8 selisih 40,33 cm (Balitbangtan, 2017).

Penelitian yang telah dilaksanakan dengan beberapa varietas unggul baru memberikan pertimbangan bagi petani sebagai pengguna untuk memilih varietas yang akan dikembangkan. Pemilihan varietas umumnya didasarkan pada sifat agronomis tanaman seperti tinggi tanaman dan jumlah anakan (Rohaeni et al. 2012). Hasil penelitian Kristamtini et al. (2016) menunjukkan nilai keragaman fenotipe dan genotipe yang luas terdapat pada karakter tinggi tanaman, jumlah anakan produktif, jumlah gabah isi/ malai, dan jumlah gabah hampa/malai. Karakter tersebut umumnya lebih banyak dikendalikan oleh faktor genetik daripada faktor lingkungan.

Hasil analisis ragam terhadap jumlah anakan menunjukkan tidak terdapat perbedaan nyata, namun jumlah anakan produktif tertinggi diperoleh pada varietas lokal Dodo Erok dibanding varietas lainnya (Tabel 2). Sedangkan panjang malai menunjukan tidak berbeda nyata namun kelima varietas yang terpanjang Inpara-8 $(21,3 \mathrm{~cm})$ disusul Dodok Erok 20,3 cm. 
Tabel 3. Jumlah gabah/malai, jumlah gabah isi/malai, jumlah gabah hanpa/malai, bobot 1000 biji dan produksi gabah kering panen (GKP) dari lima varietas yang dikaji.

\begin{tabular}{lccccc}
\hline Varietas & $\begin{array}{c}\text { Jumlah } \\
\text { gabah/ } \\
\text { malai }\end{array}$ & $\begin{array}{c}\text { Jumlah } \\
\text { gabah } \\
\text { isi/malai }\end{array}$ & $\begin{array}{c}\text { Jumlah gabah } \\
\text { hampa/malai }\end{array}$ & $\begin{array}{c}\text { Bobot 1000 } \\
\text { butir }(\mathrm{g})\end{array}$ & $\begin{array}{c}\text { Produksi } \\
\text { GKP } \\
(\mathrm{t} / \mathrm{ha})\end{array}$ \\
\hline Inpari 32 & $92,1 \mathrm{c}$ & $69,6 \mathrm{a}$ & $22,5 \mathrm{c}$ & $24,1 \mathrm{~cd}$ & $2,5 \mathrm{a}$ \\
Inpari 33 & $111,9 \mathrm{~b}$ & $74,5 \mathrm{a}$ & $37,4 \mathrm{~b}$ & $24,7 \mathrm{c}$ & $2,3 \mathrm{a}$ \\
Inpari 43 & $103,1 \mathrm{bc}$ & $73,0 \mathrm{a}$ & $30,1 \mathrm{bc}$ & $26,2 \mathrm{~b}$ & $2,7 \mathrm{a}$ \\
Inpara 8 & $140,5 \mathrm{a}$ & $85,1 \mathrm{a}$ & $55,5 \mathrm{a}$ & $23,4 \mathrm{~d}$ & $2,5 \mathrm{a}$ \\
Dodok Erok & $108,5 \mathrm{~b}$ & $81,4 \mathrm{a}$ & $27,1 \mathrm{bc}$ & $29,4 \mathrm{a}$ & $2,7 \mathrm{a}$ \\
\hline
\end{tabular}

Keterangan: Angka-angka yang diikuti huruf yang sama pada kolom yang sama menunjukkan tidak berbeda nyata berdasarkan uji lanjut Duncan pada taraf 5\%

Pada tabel 3. Jumlah gabah per-malai secara statistik berbeda nyata varietas Inpara-8 dengan keempat varietas Dodok Erok, Inpari-43,33 dan 32 sedangkan Dodok Erok dan Inpari 33 tidak berbeda. Jumlah gabah per-malai 5 varietas yang diuji gabah isi per-malai varietas tidak berbeda nyata, namun gabah isi terbanyak Inpara-8 disusul Dodok Erok. Jumlah gabah hampa berbeda nyata pada varietas Inpara-8 keempat varietas, namun Dodok Erok, Inpari-43 dan Inpari-32 tidak berbeda nyata. Namun, produktifitas uji adaptasi yang relatif rendah tersebut masih bisa ditingkatkan. Gabah hampa pada penelitian ini relatif tinggi, berkisar 15,66 - 47,23\%. Pada hasil jumlah gabah hampa dan dengan mempertimbangkan jumlah gabah total dari varietas padi yang diuji, maka hasil gabah dari varietas padi tersebut masih bisa ditingkatkan lagi, dengan lebih mengoptimalkan menaikan dosis takaran dan cara pemupukan yang lebih tepat (Rustiati \& Abdulrachman, 2011).

Bobot 1000 butir menunjukan beda sangat nyata setiap perlakuan dimana varietas lokal Dodok Erok terberat 29,4 g disusul Inpari-43 (26,2 g), Inpari 33 (24,7 g) dan Inpari-32 $(24,1 \mathrm{~g})$ kemudian paling ringan Inpara $8 \quad(23,4$ g). Menurut (Balitbangtan, 2016) bila dibandingkan dengan deskripsi padi masih sangat jauh berbeda berat untuk 1000 bulir kecuali Inpari-43 (27,1 g) sedangkan Inpari-32 $(27,1 \mathrm{~g})$, Inpari-33 (28,6 g), Inpara-8 $(28,5 \mathrm{~g})$. Enung et al. (2016) menyatakan bobot gabah juga merupakan salah satu parameter yang berhubungan erat dengan hasil tanaman padi persatuan luas.

Hasil analisis ragam menunjukkan produktivitas gabah kering panen pada lahan bukaan baru tidak beda nyata. Hasil tertinggi ditunjukkan oleh varietas Inpari-43 dan lokal Dodok Erok masing-masing 2,7 t/ha, kemudian diikuti Inpari-32 dan Inpara-8 masing-masing 2,5 t/ha dan inpari-33 (2,3 t/ha). Bila dibandingkan deskripsi padi dan hasil penelitian tergolong sangat rendah, dimana Inpari-43 (6,96 t/ha), Inpari-32 (6,30 t/ha), Inpari-33 (6,6 t/ha), Inpara-8 (4,7 t/ha) Pulitbangtan,2016. Hasil penelitian dengan deskripsi padi menunjukan ada selisih sangat jauh sekali Inpari-43 (4,27 t/ha), Inpari-32 (3,8 t/ha), Inpari-33 (4,3 t/ha) dan Inpara-8 (2,2 t/ha). Rendahnya hasil gabah pada penelitian ini disebabkan oleh tanaman mengalami kekurangan air selama pertumbuhan, $\mathrm{pH}$ tanah masih masam, air dilahan tidak bisa tersimpan. Rohanaya dan Asnawi (2012) menyatakan hasil padi ditentukan oleh komponen hasil yang dipengaruhi oleh faktor genetik dan faktor lingkungan dimana varietas tersebut ditanam. 


\section{KESIMPULAN}

Budidaya padi pada lahan sawah bukaan baru menggunakan lima varietas, menunjukan komponen pertumbuhan tidak berbeda nyata. Komponen hasil jumlah gabah, jumlah gabah hampa, berat 1000 bulir beda nyata sedangkan berat gabah isi dan gabah kering kering tidak beda nyata.

\section{DAFTAR PUSTAKA}

Agus, F. dan Irawan. 2007. Agricultural land conversion as a threat to food security and environmental quality. Jurnal Penelitian dan Pengembangan Pertanian 25(3):90-98.

BPS (Badan Pusat Statistik). 2018. Statistik Indonesia. Badan Pusat Statistik. Jakarta

BPTP Sulawesi Selatan. 2018. Laporan Hasil Analisis Tanah. Balai Pengkajian Teknologi Pertanian Sulawesi Selatan

Balitbangtan. 2017. Deskripsi Varietas unggul Baru Padi. Badan Penelitian dan Pengembangan Pertanian. Kementrian Pertanian, Jakarta

Balitbangtan. 2016. Deskripsi Varietas unggul Tanaman Pangan 2010-2016. Pusat Penelitian dan Pengembangan Tanaman Pangan. Badan Penelitian dan Pengembangan Pertanian. Kementrian Pertanian, Jakarta

Balai Penelitian Tanah. 2009. Kriteria sifat kimia tanah. Balai Penelitian Tanah. Bogor. Jawa Barat.

Distan Kab. Merauke. 2016. Laporan Tahunan. Dinas Pertanian Tanaman Pangan Kab. Merauke

Enung, S.M., A.Y Perdani, S. Indrayani, dan Suwarno. 2016. Seleksi fenotipe
Status tanah lokasi penelitian $\mathrm{pH}$ masam dan nilai tukar kation sangat rendah. Pengelolaan lahan sawah bukaan baru dalam peningkatan Produktivitas dapat dilakukan melalui pengelolaan drainase, dan pengunaan pemupukan serta pengunaan varietas yang toleran.

populasi padi gogo untuk hasil tinggi, toleran alumunium dan tahan blas pada tanah masam. Jurnal Penelitian Pertanian Tanaman Pangan 35(3): 191-197.

Endrizal dan J. Bobihoe. 2010. Pengujian beberapa galur unggulan padi dataran tinggi di Kabupaten Kerinci Propinsi Jambi. Jurnal Pengkajian dan Pengembangan Teknologi Pertanian 13(3): 175-184.

Hardjowigeno, s., H. Subaygo, M. Lutfi Rayes. 2014. Morfologi dan klasifikasi tanah. Hlm., 1-28 dalam Tanah Sawah dan Pengelolaannya. Pusat penelitian dan Pengembangan Agroklimat, Badan Litbang Pertanian.

Hardjowigeno, S. 2003. Ilmu Tanah. CV. Akademika Pressindo. Jakarta. 286 halaman.

Hanudin, E. 2000. Pedoman Analisis Kimia Tanah (Dilengkapi dengan Teori, Prosedur dan Keterangan). Jurnal Agroteksos. 21 (1). Yogyakarta. Hlmn 4-7.

Irawan. 2005. Analisis ketersdiaan beras nasional: suatu kajian simulasi pendekatan sistem dinamis. hlm. 107130 dalam Prosiding Seminar Nasional Multifungsi Pertanian dan Ketahanan Pangan. Bogor, 12 Oktober dan 24 Desember 2004. Pusat Penelitian dan Pengembangan Tanah dan Agroklimat. Bogor. 
Irundu, B. 2008. Penilaian Kualitas Tanah pada Beberapa Jenis Penggunaan Lahan di Kecamatan Liliriaja Kabupaten Sopeng. Skripsi. Universitas Hasanuddin Makasar.

Kristamtini, Sutarno, E.W. Wiranti, dan S. Widyayanti. 2016. Kemajuan genetik dan heritabilitas karakter agronomi padi beras hitam pada populasi $F 2$. Jurnal Penelitian Pertanian Tanaman Pangan. 35(2): 119-124

Rohaeni, W.R., A . Sinaga, dan M.I. Ishaq. 2012. Preferensi responden terhadap keragaan tanaman dan kualitas produk beberapa varietas unggu.

Rustiati, T., dan S. Abdulrachman. 2011. Komparatif beberapa metode penetapan kebutuhan pupuk pada tanaman padi. Prosiding Seminar Ilmiah Hasil Penelitian Padi Nasional 2010. Buku 2. Balai Besar Penelitian Tanaman Padi. Badan Penelitian dan Pengembangan Pertanian.

Rohayana, D dan R. Asnawi. 2012. Keragaan hasil varietas unggul Inpari 7 ,Inpari 10 dan Inpari 13 melalui pendekatan pengelolaan tanaman terpadu (PTT) di Kabupaten Pesawaran. Prosiding inovasi hasil penelitian dan pengkajian teknologi pertanian. BPTP Lampung.

Ritung, Sofyan dan Nata Suharta. 2007. Sebaran dan Potensi Pengambangan Lahan Sawah Bukaan Baru. dalam Buku Tanah Sawah Bukaan Baru.
Balai Besar Litbang Sumber Daya Lahan Pertanian. Hal 5-24.

Suphendi, E. Rustiadi, dan B. Juanda. 2014. Optimasi pendapatan petani melalui System of Rice Intensification di Kabupaten Indramayu. Jurnal Pengkajian dan Pengembangan Teknologi Pertanian 17(2): 106-114.

Sudaryanto, T. dan N. Ilham. 2001. Upaya peningkatan efisiensi usaha ternak ditinjau dari aspek agribisnis yang berdaya saing. Apresiasi Teknis Program Litkaji Sistem Usahatani Tanaman Ternak (Crop Animal System), Puslitbangnak, Bogor.

Sudaryono, 2009. Tingkat kesuburan tanah ultisol pada lahan pertambangan batubara Sangatta Kalimantan Timur. J. Tek. Ling. 10 (3):337-346.

TIM FKPR Badan Litbang Pertanian Sub Tim Merauke, 2014. Kunjungan Kerja Tematik dan Penyusunan Model Percepatan dan Penguatan Pembangunan Pertanian Berbasis Inovasi di Wilayah Perbatasan Merauke, Provinsi Papua. Laporan Akhir. Badan Penelitian dan Pengembangan Pertanian.

Prasetyo, H.P,. J,S. Adiningsih, K. Subaygono. Dan R.M. Sumangkalit. 2004. Mineralogi, Kimia, Fisika dan biologi lahan sawah. hlm 28-92. dalam Tanah Sawah dan Pengelolaannya. Pusat penelitian dan Pengembangan Agroklimat, Badan Litbang Pertanian. 